Institute of $\mathbf{F}_{\text {ood and }} \mathbf{A}_{\text {gricultural }} \mathbf{S}_{\text {ciences }}$

\title{
Effect of Stocking Rate on Measures of Cow-Calf Productivity and Nutrient Loads in Surface Water Runoff 1
}

John Arthington, Patrick Bohlen, and Fritz Roka²

The presence of beef cattle at three stocking rates had no impact on nutrient load ( $\mathrm{P}$ and $\mathrm{N}$ ) of surface runoff water when compared with pastures containing no cattle.

\section{Rationale}

Florida ranks third among states east of the Mississippi river and $12^{\text {th }}$ nationally in total number of beef cows (Florida Agricultural Statistics Service, 2002 Report). In contrast with other states, that may feed or background many of their weaned calves, more than $75 \%$ of Florida's calves are marketed each year. The beef industry in Florida is based primarily on calves that are conceived, born, and weaned in south Florida. Eleven of Florida's 15 top counties by cow number are located south of Orlando. About $80 \%$ of Florida's total cow inventory resides in south Florida.

South Florida is an important region for addressing sustainable management of grazing systems because the extensive subtropical pastures in the region intersect with highly sensitive natural systems. These systems include Lake Okeechobee and the Everglades, which are the focus of major state and federal environmental efforts. The region's pasture and rangelands provide an essential landscape for preserving the ecology of south Florida. Lake Okeechobee, the receiving water body in the region, has been threatened by increased phosphorus concentrations. The effect of ranching activities on surface water quality is an issue of increasing importance to public policy makers.

To investigate this important topic, the University of Florida-IFAS formed a partnership with Archbold Biological Station, South Florida Water Management District, USDA-ARS, Florida Department of Agriculture and Consumer Services, and the Florida Cattlemens Association. The goal of this partnership is to design sustainable, environmentally sensitive management practices for cattle grazing operations. This partnership is currently completing a comprehensive research study investigating, among other things, the interrelationship between beef cow-calf stocking rate and surface water quality.

1. This document is AN141, one of a series of the Animal Sciences Department, Florida Cooperative Extension Service, Institute of Food and Agricultural Sciences, University of Florida. Original publication date May 2003. Visit the EDIS Web Site at http://edis.ifas.ufl.edu.

2. John Arthington, assistant professor, Animal Sciences, Range Cattle Research and Education Center, Cooperative Extension Service, Institute of Food and Agricultural Sciences, University of Florida, Gainesville, 32611 and MacArthur Agro-ecology Research Center 


\section{Study Site and Experimental Methods}

This research was conducted at Buck Island Ranch near Lake Placid, Florida at the site of the MacArthur Agro-ecology Research Center (MAERC; $\left.27^{\circ}, 09^{\prime} \mathrm{N}, 81^{\circ}, 12^{\prime} \mathrm{W}\right)$ over three production cycles from 1999 to 2001. Both summer and winter pastures were used. Summer pastures consisted of eight, 50 -acre pastures with established bahiagrass on flatwoods soils with extensive ditching to facilitate drainage. Winter pastures consisted of eight, 80-acre pastures with mixed forages, predominantly bahiagrass, on similar soils with less extensive ditching

Three stocking rate treatments were used which represented 3.7, 6.5, and 8.6 acres per cow over the combined total of 130 acres of the summer (50 acre) and winter (80 acre) pastures. These treatments were chosen to illustrate differing levels of cattle stocking rates common in south Florida (high, medium, and low, respectively). A fourth treatment containing no cows (Control) was also used. Summer but not winter pastures received a spring application of ammonium nitrate fertilizer (50 lb N/acre).

Pregnant, Brahman crossbred cows, ranging in age from 4 to 9 years, were used in the stocking rate study. Complications with drought and animal handling allowed for data collection on cows for only one complete production cycle (winter 1999 until weaning 2000). Calf data for two complete summer periods were collected (1999 and 2000). All cows were exposed to bulls (two per pasture) for 120 days starting in mid-January. Cow body condition was scored on a 1 to 9 scale $(1=$ emaciated and $9=$ obese) when they were moved to winter pastures (start of production cycle), moved to summer pastures, and at weaning (end of production cycle). Calf weight was collected when cows were moved into summer pastures and again at weaning.

The economic impact of reducing stocking rates was developed using SPA (Standardized Performance Analysis). Five years of SPA data were collected from the commercial ranch at Buck Island. These data provided an annual average of itemized production costs, calving percentages, and calf weaning weights. Costs were grouped into two categories - variable and fixed costs. Variable costs included supplemental feed, veterinary supplies, pasture fertilization, and ranch labor. Variable costs remained fairly constant per head. Fixed costs, on the other hand, did not change with herd size. While costs such as equipment depreciation, office overhead, cow pen and fence repairs changed annually, these costs were independent of herd size.

Experimental pastures were separated by berms and all surface runoff from each pasture collected in ditches and flowed through a separate flume. Each flume was fully instrumented to record the total amount of runoff and to take automatic water samples during periods of flow. Water samples were analyzed for total phosphorus and nitrogen.

\section{Results}

Cows entering winter pastures in 1999 had similar body condition across stocking densities (Table 1). However, cows assigned to medium and high stocking rates had lower body condition at the end of the winter grazing period (Table 1). This difference in body condition declined following 98 days of summer grazing, as cattle assigned to medium and high stocking rates regained this lost body condition (Table 1), such that at weaning, cows from all stocking densities had similar body condition.

Calf performance during the summer grazing period was similar, irrespective of stocking rate (Table 2). Production, as measured by pounds of calf weaned per acre of dedicated land was greater for high compared to medium and low stocking rates (Table 2). Stocking density had no impact on cow pregnancy rate.

Based on SPA data, total operating costs declined from the highest to lowest stocking rate. However, because fixed costs remain constant, the unit cow costs increased from $\$ 167$ per cow at the highest stocking rate to $\$ 255$ per cow at the lowest stocking rate. Assuming a 70 percent calf crop and weaning weights of 450 pounds, break-even prices increased from $\$ 53$ to $\$ 81$ per hundred-weight for the high and low stocking rate, respectively. Based on season average Florida calf prices as reported by the Florida 
Agricultural Statistics Service (FASS), a rancher who stocked at the highest rate would have earned positive net returns every year between 1994 and 2000. On the other hand, if a rancher stocked at the lowest rate, positive net returns would have earned in only one year between 1994 and 2000.

Annual rainfall varied significantly from 1998-2001 (Table 3). Year 2000 was the driest on record in this region and water runoff amounts from the pastures were accordingly very low that year. Recorded runoff amounts were greatest in 2001 and total nutrient loads increased with increasing amounts of runoff.

Cattle stocking rate did not effect concentrations or loads of total $\mathrm{P}$ or $\mathrm{N}$ measured in runoff from the plots in $1998-2001$ (Table 4). In fact, control pastures containing no cattle provided similar amounts of total $\mathrm{P}$ and $\mathrm{N}$ in runoff water compared to pastures containing cattle. Summer pastures consistently delivered greater $P$ loads in runoff than did the winter pastures in all years except the drought year of 2000 (Table 5). Loads of total $\mathrm{N}$ were greater from summer than winter pastures in 1999 and 2001 (Table 5).

That the loads of $\mathrm{N}$ and $\mathrm{P}$ were greater in the summer pasture runoff than in the winter pasture runoff was likely due to differences in the long-term fertilization history of the two pasture sites. The improved summer pastures are fertilized annually with $\mathrm{N}$ fertilizer and, although they currently receive no $\mathrm{P}$ fertilizer, they were fertilized annually with $\mathrm{P}$ fertilizer (30-80 lbs. $\mathrm{P}_{2} \mathrm{O}_{5}$ per acre) for at least 15-20 years before 1987, at which time $P$ fertilizer use was discontinued. The semi-native winter range pastures, by contrast, have never been fertilized. The long term $\mathrm{P}$ fertilization of summer pastures likely caused $\mathrm{P}$ to accumulate in surface soils in excess of plant demand, increasing the susceptibility to loss in surface runoff. Examination of uranium isotopes in soil and water from our experimental pastures indicated that soil and runoff water from summer pastures contained an elevated concentration of uranium with an isotopic ratio characteristic of $\mathrm{P}$ fertilizer.

\section{Implications}

The high stocking density used in this study is similar to common Florida beef cow/calf production practices. In this evaluation, the high stocking density supported similar cow and calf performance as the lower stocking densities. When pasture productivity was considered, the high stocking density provided the most weight of weaned calf per unit of dedicated land. A change in stocking rate has a one-to-one relationship with ranch revenues. If stocking rates decrease by 10 percent, ranch revenues decrease by 10 percent as well. At the same time, unit cow costs increase at an increasing rate as fewer brood cows are left to support the ranchs fixed costs. Consequently, ranch profitability decreases as stocking rates decline.

Stocking rate did not affect the total loads of $\mathrm{P}$ and $\mathrm{N}$ in surface runoff. In fact, similar amounts of total $\mathrm{P}$ and $\mathrm{N}$ in surface water runoff were found in pastures containing no cattle compared to pastures stocked with cattle over three production cycles. The improved summer pastures provided 5 to 7 times more total $\mathrm{P}$ and $\mathrm{N}$ in surface water runoff compared to the semi-native winter pastures. This is apparently due to use of $\mathrm{P}$ fertilizer before 1987 and does not appear to be dependent upon the current presence of cattle on these pastures.

\section{Additional Information}

Expanded information on all phases of this research effort is available in individual discipline manuscripts. Please contact one of the authors for further information. 
Table 1. Effect of stocking rate on cow body condition score (BCS)

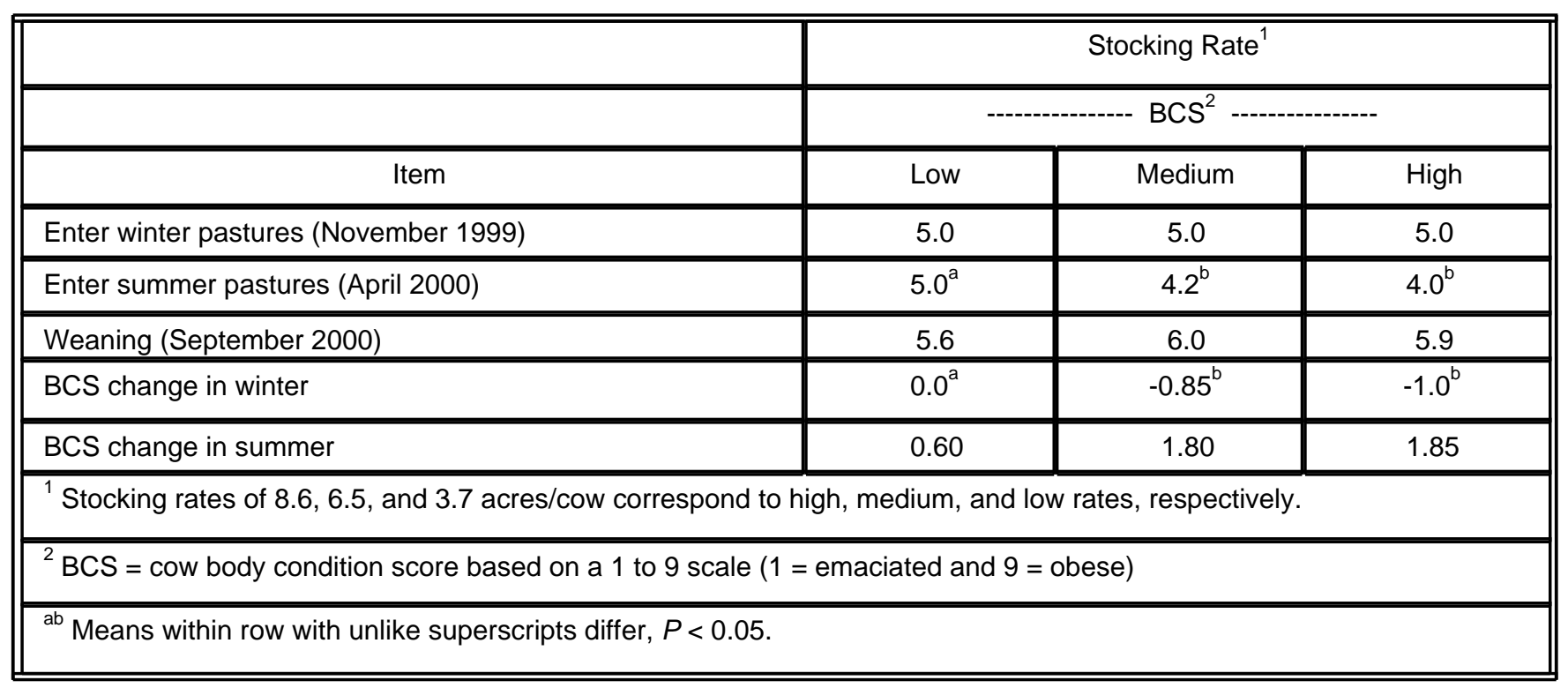

Table 2. Effect of stocking rate on calf performance during the summer months (average 1999 and 2000)

\begin{tabular}{|c|c|c|c|}
\hline & \multicolumn{3}{|c|}{ Stocking Rate ${ }^{1}$} \\
\hline Item & Low & Medium & High \\
\hline & \multicolumn{3}{|c|}{----------------- lb ------------------ } \\
\hline Enter Summer Pastures ${ }^{2}$ & 376 & 374 & 351 \\
\hline Weaning $^{2}$ & 544 & 522 & 527 \\
\hline ADG & 1.95 & 1.74 & 2.03 \\
\hline Production, lb/acre ${ }^{3}$ & $60.4^{\mathrm{a}}$ & $77.4^{\mathrm{b}}$ & $136.5^{\mathrm{C}}$ \\
\hline \multicolumn{4}{|c|}{${ }^{1}$ Stocking rates of $8.6,6.5$, and 3.7 acres/cow correspond to high, medium, and low rates, respectively. } \\
\hline \multicolumn{4}{|c|}{${ }^{2}$ All measures of calf data are adjusted for sex. } \\
\hline \multicolumn{4}{|c|}{${ }^{3}$ Production $/$ acre $=$ weaning rate for all treatments $\mathrm{x}$ sex-adjusted calf gain $\mathrm{x}$ stocking rate $/ 130$ acres. } \\
\hline
\end{tabular}

Table 3.

\begin{tabular}{|l|c|c|c|c||}
\hline \hline & \multicolumn{3}{|c||}{ Year } \\
\hline Item & $1998^{1}$ & 1999 & 2000 & 2001 \\
\hline Rainfall $^{2}$ & & \multicolumn{3}{|c||}{} \\
\hline Summer pasture runoff & 54.52 & 45.11 & 29.23 & 50.54 \\
\hline \hline
\end{tabular}


Table 3.

\begin{tabular}{|c|c|c|c|c|}
\hline & \multicolumn{4}{|c|}{ Year } \\
\hline Item & $1998^{1}$ & 1999 & 2000 & 2001 \\
\hline & \multicolumn{4}{|c|}{ 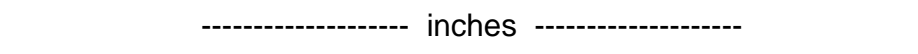 } \\
\hline Winter pasture runoff & 7.41 & 4.73 & 0.53 & 9.55 \\
\hline \multicolumn{5}{|c|}{${ }^{1}$ Runoff measurements in 1998 did not start until late spring and do not represent total runoff for the year. } \\
\hline
\end{tabular}

Table 4. Nutrient loads in surface water runoff from summer and winter pastures stocked at different cattle rates (average 1998-2001).

\begin{tabular}{|c|c|c|c|c|}
\hline Stocking rate $^{1}$ & \multicolumn{2}{|c|}{ Summer pastures } & \multicolumn{2}{|c|}{ Winter pastures } \\
\hline Control & 1.22 & 5.49 & 0.21 & 5.17 \\
\hline Low & 1.27 & 5.23 & 0.17 & 4.01 \\
\hline High & 1.15 & 5.51 & 0.22 & 4.54 \\
\hline
\end{tabular}

Table 5. Nutrient loads of surface water runoff from summer and winter pastures (average 1998-2001).

\begin{tabular}{|c|c|c|}
\hline & \multicolumn{2}{|c|}{ Mean nutrient load } \\
\hline \multirow[t]{2}{*}{ Pasture type } & Total $\mathrm{P}^{\mathrm{a}}$ & Total $\mathrm{N}^{\mathrm{b}}$ \\
\hline & \multicolumn{2}{|c|}{-------- lb/acre --------- } \\
\hline Summer & 1.19 & 5.77 \\
\hline Winter & $0.18^{\mathrm{b}}$ & 4.53 \\
\hline Pooled SEM & 0.07 & 0.59 \\
\hline \multicolumn{3}{|c|}{${ }^{\mathrm{a}}$ Significant differences between pasture types for total $\mathrm{P}$ were noted in each year except the drought of $2000, P<0.0$} \\
\hline \multicolumn{3}{|c|}{${ }^{\mathrm{b}}$ Significant differences between pasture types for total $\mathrm{N}$ were noted in 1999 and $2001, P<0.05$. } \\
\hline
\end{tabular}

